\section{RESEARCH TRENDS IN HYDROLOGICAL MODELLING}

\author{
Jazuri Abdullaha, Nur Shazwani Muhammadb*, Siti Asiah \\ Muhammadb, Noor Farahain Mohammad Aminb, Wardah Tahirc
}

aFaculty of Civil Engineering, Universiti Teknologi MARA, 40450 Shah Alam, Selangor, Malaysia

bSmart and Sustainable Township Research Centre, Faculty of Engineering and Built Environment,Universiti Kebangsaan Malaysia, Bangi, Selangor, Malaysia

cFaculty of Civil Engineering, Universiti Teknologi MARA, 40450 Shah Alam, Selangor, Malaysia
Article history

Received

30 August 2018

Received in revised form

14 March 2019

Accepted

19 March 2019

Published online

25 June 2019

*Corresponding author shazwani.muhammad@ ukm.edu.my

\begin{abstract}
This paper reviews the hydrological modelling research trends as published in the recent years. Three-round literature review technique was used to study journal papers published that are related to the hydrological modelling. The published papers were searched by using Web of Sciences engine. The first and second round were to examine the published papers as a general perspective in a wide range of hydrological modelling through title and keywords whereas the third round was to establish 139 papers as target publications through abstract and main texts. 139 target papers were analyzed in terms of (1) journals that produced two or more target papers, (2) research origin, (3) authors, (4) research center and (5) most cited papers. The score matric was used to rank these items. The results of analysis produced (1) 6 journals target papers, (2) United states got the highest score with 27.71 score for research origin, (3) Keith Beven got the highest score 8.03 for an active researcher, (4) Lancaster University got the highest score 9.93 for research center and (5) Keith Beven and Andrew Binley had the most cited papers.
\end{abstract}

Keywords: Hydrological modelling, flood modelling, rainfall-runoff modelling, ISI journals, research trends

\begin{abstract}
Abstrak
Kajian ini untuk mengkaji trend penyelidikan pemodelan hidrologi seperti yang diterbitkan pada tahun-tahun kebelakangan ini. Teknik peninjauan kesusteraan tiga bulat digunakan untuk mengkaji kertas jurnal yang diterbitkan yang berkaitan dengan pemodelan hidrologi. Kertas yang diterbitkan telah dicari dengan menggunakan enjin Web Sains. Pusingan pertama dan kedua adalah untuk mengkaji kertas-kertas yang diterbitkan sebagai perspektif umum dalam pemodelan hidrologi yang luas melalui tajuk dan kata kunci manakala pusingan ketiga adalah untuk menetapkan 139 kertas sebagai penerbitan sasaran melalui teks-teks abstrak dan utama. 139 kertas kerja dianalisis dari segi (1) jurnal yang menghasilkan dua atau lebih kertas sasaran, (2) sumber penyelidikan, (3) pengarang, (4) pusat penyelidikan dan (5) kertas paling banyak dikutip. Skor matrik digunakan untuk menilai item-item ini. Hasil analisis yang dihasilkan (1) 6 jurnal kertas sasaran, (2) Negara Amerika mendapat skor tertinggi dengan skor 27.71 untuk penyelidikan asal, (3) Keith Beven mendapat skor tertinggi 8.03 untuk penyelidik aktif, (4) Lancaster University mendapat skor tertinggi 9.93 untuk pusat penyelidikan dan (5) Keith Beven dan Andrew Binley mempunyai kertas paling banyak.
\end{abstract}

Kata kunci: Pemodelan hidrologi, pemodelan banjir, pemodelan hujan-air larian, jurnal ISI, trend penyelidikan

(C) 2019 Penerbit UTM Press. All rights reserved 


\subsection{INTRODUCTION}

The water related challenges are huge and will increase in the future. In response to these challenges, hydrological modelling has been developed to analyse, understand and explore solutions for sustainable water management, to the decision makers and operational water managers. In order to test new hypotheses and to obtain a better understanding regarding hydrological processes, the most needed tool is hydrological modeling [1]. To understand hydrologic processes, a large amount of detailed quantitative measurements is required at different spatial and temporal scales. The strength of hydrological models is that they can provide output at high temporal and spatial resolutions, and for hydrological processes that are difficult to observe on the large scale that they are generally applied on. Hydrological models therefore enable us to gain insight into hydrologic processes using a limited number of measurements [2].

The hydrological modelling can generally be classified into empirical, conceptual and physically based models [3]. The empirical model is the data based or black box model that involves the mathematical equations and derives value from available time series. The conceptual model is parametric or grey box model based on modelling of reservoirs and include semi empirical equations with a physical basis. The physically based model is mechanistic or white box model based on spatial distribution and evaluation of parameters describing physical characteristics [3].

Some researchers define the empirical model as soft computing techniques [4] with given examples of the model are Artificial Neural Networks (ANN) (e.g. [5]), Genetic Algorithms (GA) (e.g. [6]), Fuzzy Logic (FL) (e.g. [7]) and unit hydrograph. HBV model (e.g. [8]) and TOPMODEL (e.g. [9]) are example of conceptual model. Physical based models have recently increasing in the market of software with examples such as MIKESHE (e.g. [10]), SWAT (e.g. [11]), InfoWorks and TREX (e.g. [12]). Blomqvist et al., (2013) outline the steps in model application which include problem identification, data availability, choice of model, determination of parameter value, validation and problem solving [13].

The successful application of a hydrological modelling depends on how well the model is calibrated. The difficulties in the application of such methods are interdependence between model parameters, discontinuities or points on the response surface, local optima on the response surface and the scaling of parameters [14]. The limitation in this modelling is in terms of understanding and predicting hydrologic change through the spatial characteristics. The data limitations may be the key cause of this [15].

The publications especially related to academics will be the sources for the researcher in their research works. The publication of this modeling article in academic journals had started from the year 1986 [16] to the recent distributed physically-meaningful models [17-19]. [20] had reviewed the scale issues in hydrological modeling in while the recent review is regarding the parameters involved in the certain model [3].

Nowadays, hydrological modeling works have taken over the most important tasks in problem solving in hydrology [21] which subsequently leads to the increase in the publication of this topic year by year. The contents in the research and the software used have also been upgrading in line with the technology development. In this study, the authors had reviewed most of the academic journal publications to analyze the research trends and identify the patterns of hydrological modeling publications. The retrieval from academic journals is regarded as the most effective approach for the research community, especially for new researchers in particular, to gain in-depth insight into the research trends. In this regard, a systematic review of hydrological modelling success factors had been undertaken with the following derived objectives: 1) To ascertain the annual publication trends of hydrological modelling from 1980 to 2010; 2) To identify authors' origin/country and the active contributors in exploring the hydrological modelling from 1980 to 2010; and 3) To identify countries with most published papers on the hydrological modelling.

\subsection{METHODOLOGY}

Searching on an academic journal particularly on the specific topic is necessary in order to have a comprehensive review and analysis on previous research studies [22]. Therefore, this study had adopted a combination of comprehensive methods used by [23], [24] and [25]. The three round literature reviews were conducted to document the research study of hydrology modelling. A flowchart of the three round literature reviews was illustrated in Figure 1. Therefore, this research method was developed to ensure no papers with high relevancy are left out.

In Stage 1, the search engine "Scopus" was used as the main source to obtain paper. This search engine was chosen because it covers most of the research journals [24]. To ensure that no paper will be missed, additional search engine, i.e. Web of Science and Google Scholar were also used to extract the papers that relate to the "titles, abstract/keywords". These additional search engines were used as it is believed that they have better search engine in term of coverage and accuracy, as compared to other search engines. These search engines are also popular among hydrological modeler. Since the main subject matter for this study is modelling, two different spellings had been considered, i.e. modelling and modeling to cover papers written both in US English and British English. The subject areas 
to be searched were hydrology modelling/modeling, hydrological modelling/modeling, rainfall-runoff modelling/modeling, runoff modelling/modeling, discharges modelling/modeling, flood modelling/modeling, extreme discharge modelling/modeling. These terms are classified into hydrological modelling. The complete search code is listed as follows:

TITLE-ABS-KEY ("hydrology modelling/modeling" OR "hydrological modelling/modeling" OR "rainfallrunoff modelling/modeling" OR "runoff modelling/modeling" "discharges modelling/modeling" "OR "flood modelling/modeling" OR "extreme discharge modelling/modeling")

The search is strictly limited to hydrological modelling. However, there are high possibility that some unwanted papers appeared. To narrow down the search finding, all search results were only analyzed for the paper published in top-ranked journals. This process was done in stage 2, which main purpose is to testify the level of attention in hydrological modelling.

In stage 3, the scope was narrowed down by visual examination of abstracts and main texts. Any unrelated papers were excluded and papers addressing hydrology modelling issues were extracted as selected papers to obtain the information which are contents, research origin, research centre, active researcher, most cited papers and research pattern. The calculation of score uses a quantitative method by [26] to differentiate the contribution of each author in a coauthored paper. The score calculation was chosen because of its simplicity to represent the actual contribution every author. Typically, the first author contributes more than the second author and the second more than the third and so on. Each publication was given one point, no matter how many authors there were. If more than one author participated in producing the paper, the one point was divided into corresponding parts for each author [25]. The score calculation formula is shown as follows.

$$
\text { Score }=\frac{1.5^{n-1}}{\sum_{\mathrm{i}=1}^{\mathrm{n}} 1.5^{\mathrm{n}-\mathrm{i}}}
$$

Where $n$ means the number of authors that contributed to the paper and $i$ is the order of each specific writer. A detailed score distribution for authors is presented in Table 1, which was produced using formula above.
Table 1 Score matrix for more than 1 author

\begin{tabular}{llllll}
\hline \multirow{2}{*}{ No. of author } & \multicolumn{6}{l}{ Order of author } \\
\cline { 2 - 6 } & $\mathbf{1}$ & $\mathbf{2}$ & $\mathbf{3}$ & $\mathbf{4}$ & $\mathbf{5}$ \\
\hline 1 & 1 & & & & \\
2 & 0.60 & 0.40 & & & \\
3 & 0.47 & 0.32 & 0.21 & & \\
4 & 0.42 & 0.28 & 0.18 & 0.12 & \\
5 & 0.38 & 0.26 & 0.17 & 0.11 & 0.08 \\
\hline
\end{tabular}

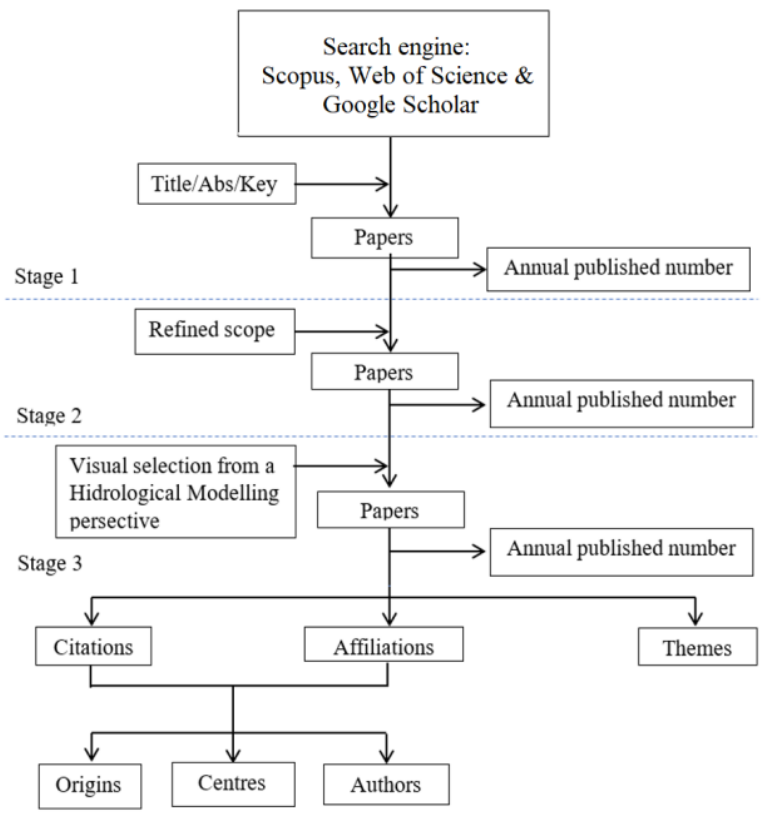

Figure 1 The research flowchart

\subsection{RESULTS AND DISCUSSION}

\subsection{Holistic View of Hydrology Modelling Papers Published}

The search result derived from stage 1 until stage 3 produced 8 journals with 5 different publishers. These journals are name based on their rank, as shown in Table 2, (based on number of paper published) Journal of Hydrology $(\mathrm{JH})$, Journal of Advanced in Water Resources (AWR), Hydrological Sciences (HS), Hydrology and Earth System Sciences (HESS), Hydrological Processes (HP), Water Resources Research (HRR), Water Research (WR) and Water Resources Management (WRM). There are 139 related papers in total which had been published by these journals. JH was found to publish the highest number of papers, followed by AWR, which are 28 papers. Two journals, i.e. WR and WRM, were found published less than 10 numbers of papers. Among these 8 journals, Elsevier Publisher was found to publish highest number of papers, i.e. 83 papers. Three (3) journals published under Elsevier are JH, AWR and WR. Wiley Publisher published in total of 24 numbers of papers in their two (2) different journals, i.e. HP and WRR, with 12 number of papers each journal. The remaining of the journals is published by 
Taylor \& Francis (HSJ), EGU (HESS) and Springer (WRM).

\subsection{Active Authors, Research Centers and Origins, and Regional Concerns}

The origin of the author, author, research/institution center and most paper cited were ranked based on the score matric as shown in Table 1. The score will be assigned for each author and finally will accumulate based on the category to be evaluated. For instance, Table 3 shows the research score of each author based on origin country. The United States has the highest score with 27.71 while Tanzania has the lowest score with 0.40 in post hydrology modelling publications. These values were assigned by accumulating origin all authors contributed for each country. For instance, one paper with title of "Effects of spatial variability and scale with implications to hydrologic modeling" was chosen [27]. This paper was written by four (4) authors, i.e. Wood, Sivapalan, Beven and Band (1988) and each author will have a score of $0.42,0.28,0.18$ and 0.12 , respectively (refer to Table 1). A score of 0.82 (from Wood -0.42 , Sorooshian - 0.28 and Band - 0.12) is awarded to United States and the score of 0.18 , i.e. contributed by Beven, is awarded to United Kingdom. This analysis was also applied to calculate the score of each author and research centres. From Table 3, three countries, i.e. the United States, the United Kingdom and Australia, had published the highest number of hydrological modelling papers with scores of 27.71 , 15.70 and 14.30, respectively. These countries can produce large number of publications because of the international collaboration between them, as shown by Wood et al. (1988) for their paper entitled "Effects of spatial variability and scale with implications to hydrologic modeling" [27]. One of the reasons why US can have highest score is because this country has 49 different research centers with 103 researchers and had produced 46 papers. The total percentage number of papers contributed by these countries is $44 \%$ (92 in 208). The high contribution of the three countries to hydrological modelling can be due to:1) international collaboration in producing papers, 2) the hydrological modelling study is dominant by these three countries and 3) high number of research centers and researchers.

Table 2 Journals that produced two or more target papers

\begin{tabular}{lc}
\hline $\begin{array}{c}\text { Journal title (Publisher; Impact Factor (IF) - as for } \\
\text { 2016) }\end{array}$ & $\begin{array}{c}\text { Number } \\
\text { of } \\
\text { journal }\end{array}$ \\
\hline Journal of hydrology (Elsevier; IF: 3.483) & 48 \\
\hline Advances in water resources (Elsevier; IF: 3.221) & 28 \\
\hline $\begin{array}{l}\text { Hydrological sciences journal (Taylor \& Francis; IF: } \\
\text { 2.222) }\end{array}$ & 15 \\
\hline $\begin{array}{l}\text { Hydrology and earth system sciences (EGU; IF: } \\
\text { 4.437) }\end{array}$ & 15 \\
\hline Hydrological processes (Wiley; IF: 3.014) & 12 \\
\hline Water resources research (Wiley; IF: 4.397) & 12 \\
\hline Water research (Elsevier; IF: 6.942) & 7 \\
\hline Water resources management (Springer; IF: 2.848) & 2 \\
\hline
\end{tabular}

Table 3 Research origin of published Hydrological Modelling papers

\begin{tabular}{lcccc}
\hline \multicolumn{1}{c}{ Origin } & $\begin{array}{c}\text { Number } \\
\text { of } \\
\text { research } \\
\text { centres }\end{array}$ & $\begin{array}{c}\text { Number of } \\
\text { researches }\end{array}$ & $\begin{array}{c}\text { Number } \\
\text { of } \\
\text { papers }\end{array}$ & Score \\
\hline United States (US) & 49 & 103 & 46 & 27.71 \\
\hline $\begin{array}{l}\text { United Kingdom } \\
\text { (UK) }\end{array}$ & 14 & 34 & 24 & 15.70 \\
\hline Australia & 28 & 47 & 22 & 14.30 \\
\hline China & 26 & 36 & 13 & 9.26 \\
\hline Canada & 15 & 35 & 12 & 8.65 \\
\hline France & 14 & 27 & 8 & 7.93 \\
\hline Netherlands & 10 & 20 & 10 & 6.85 \\
\hline Italy & 7 & 16 & 7 & 3.92 \\
\hline india & 6 & 7 & 4 & 3.60 \\
\hline Denmark & 8 & 15 & 4 & 3.49 \\
\hline Nonway & 9 & 11 & 5 & 3.31 \\
\hline Germany & 9 & 19 & 6 & 2.77 \\
\hline Spain & 11 & 13 & 5 & 2.71 \\
\hline Iran & 3 & 5 & 3 & 2.60 \\
\hline South Africa & 4 & 4 & 4 & 2.40 \\
\hline Turkey & 3 & 6 & 2 & 2.00 \\
\hline New Zealand & 3 & 5 & 3 & 1.72 \\
\hline Sweden & 3 & 5 & 4 & 1.64 \\
\hline Equador & 2 & 3 & 2 & 1.60 \\
\hline Ireland & 2 & 5 & 2 & 1.50 \\
\hline South Korean & 5 & 8 & 2 & 1.42 \\
\hline Switzerland & 5 & 8 & 3 & 1.10 \\
\hline Poland & 2 & 2 & 2 & 0.68 \\
\hline Thailand & 2 & 2 & 2 & 0.68 \\
\hline Tanzania & 2 & 2 & 0.40 \\
\hline & & & & \\
\hline & 2 & 2 & & \\
\hline
\end{tabular}

Table 4 shows the researchers involved in two or more target papers. The top ten (10) highest score by author are from the United State, the United Kingdom and Australia. Total percentage contribution by these authors (excluding from Norway and South Africa) is 48.8\% (61 in 125). The statistic in Table 4 support findings in Table 3 , as discussed before. Beven, Singh and Sivapalan had produced 11 papers respectively but different in score. Beven recorded the highest score with 8.03 point is a researcher from Lancaster University, United Kingdom. He has the highest score because he authored 11 papers. It should be noted that most of the time, he wrote these papers as a single author or less than 3 authors. Singh recorded the second highest score with 5.28 point is from Lousiana University from United States while Sivapalan recorded the third highest score with 4.27 point is from Lancaster University, United Kingdom.

Table 4 Researchers involved in two or more papers

\begin{tabular}{|c|c|c|c|c|}
\hline Researchers & Affiliation & Country & $\begin{array}{l}\text { No. of } \\
\text { papers }\end{array}$ & Score \\
\hline K. Beven & $\begin{array}{l}\text { Lancaster } \\
\text { University }\end{array}$ & UK & 11 & 8.03 \\
\hline V.P. Singh & $\begin{array}{ll}\text { Lovisiana } & \text { State } \\
\text { University } & \\
\end{array}$ & USA & 11 & 5.28 \\
\hline $\begin{array}{l}\text { M. } \\
\text { Sivapalan }\end{array}$ & $\begin{array}{l}\text { Lancaster } \\
\text { University }\end{array}$ & UK & 11 & 4.27 \\
\hline $\begin{array}{l}\text { S. } \\
\text { Sorooshian }\end{array}$ & $\begin{array}{ll}\text { University } \\
\text { Arizona }\end{array}$ & USA & 10 & 2.05 \\
\hline
\end{tabular}




\begin{tabular}{|c|c|c|c|c|}
\hline Researchers & Affiliation & Country & $\begin{array}{l}\text { No. of } \\
\text { papers }\end{array}$ & Score \\
\hline H. V. Gupta & $\begin{array}{l}\text { University of } \\
\text { Arizona }\end{array}$ & USA & 7 & 1.58 \\
\hline V. K. Gupta & $\begin{array}{l}\text { University of } \\
\text { Arizona }\end{array}$ & USA & 5 & 2.39 \\
\hline $\begin{array}{l}\text { Chong- } \\
\text { YuXu }\end{array}$ & University of Oslo & Norway & 4 & 1.64 \\
\hline G. Blöschl & $\begin{array}{l}\text { The Australian } \\
\text { National } \\
\text { University }\end{array}$ & Australia & 3 & 1.35 \\
\hline Eric F.wood & $\begin{array}{l}\text { Princeton } \\
\text { University }\end{array}$ & USA & 3 & 1.16 \\
\hline Tumbo, M & Rhodes university & $\begin{array}{l}\text { South } \\
\text { Africa }\end{array}$ & 2 & 1.00 \\
\hline $\begin{array}{ll}\text { Newsha } & K . \\
\text { Ajami } & \\
\end{array}$ & $\begin{array}{l}\text { University } \\
\text { California }\end{array}$ & USA & 2 & 0.89 \\
\hline Bárdossy, A & $\begin{array}{l}\text { University of } \\
\text { Stuttgart }\end{array}$ & Germany & 2 & 0.87 \\
\hline $\begin{array}{l}\text { Hamid } \\
\text { Moradkhani }\end{array}$ & $\begin{array}{l}\text { University } \\
\text { California }\end{array}$ & USA & 2 & 0.84 \\
\hline $\begin{array}{ll}\text { Jasper } & \text { A. } \\
\text { Vrugt } & \\
\end{array}$ & $\begin{array}{ll}\text { University } & \text { of } \\
\text { Amsterdam } & \\
\end{array}$ & $\begin{array}{l}\text { Netherlan } \\
\text { ds }\end{array}$ & 2 & 0.80 \\
\hline Zhang, Y., & $\begin{array}{l}\text { Csiro land and } \\
\text { water flagship }\end{array}$ & Australia & 2 & 0.80 \\
\hline Zhang, $\mathrm{H}$. & $\begin{array}{l}\text { University of } \\
\text { regina }\end{array}$ & Canada & 2 & 0.77 \\
\hline Zhang, X., & $\begin{array}{l}\text { Earth and } \\
\text { environmental } \\
\text { sciences division }\end{array}$ & USA & 2 & 0.70 \\
\hline $\begin{array}{l}\text { Montanari, } \\
\text { A., }\end{array}$ & $\begin{array}{l}\text { University } \\
\text { bologna }\end{array}$ & Italy & 2 & 0.68 \\
\hline Kuo-Lin Hsu & $\begin{array}{l}\text { University of } \\
\text { California }\end{array}$ & USA & 2 & 0.65 \\
\hline Engeland, $\mathrm{K}$ & University of Oslo & Norway & 2 & 0.59 \\
\hline Brissette, F. & $\begin{array}{l}\text { University of } \\
\text { quebec } \\
\text { montreal }\end{array}$ & Canada & 2 & 0.57 \\
\hline $\begin{array}{l}\text { Huang, G. } \\
\text { H. }\end{array}$ & $\begin{array}{l}\text { University of } \\
\text { regina }\end{array}$ & Canada & 2 & 0.53 \\
\hline $\begin{array}{l}\text { Andréassian } \\
, \vee .\end{array}$ & $\begin{array}{l}\text { Irstea,hydrosyste } \\
\text { ms and } \\
\text { bioprocesses } \\
\text { research unit }\end{array}$ & France & 2 & 0.53 \\
\hline Perrin, C. & $\begin{array}{l}\text { Irstea,hydrosyste } \\
\text { ms and } \\
\text { bioprocesses } \\
\text { research unit }\end{array}$ & France & 2 & 0.53 \\
\hline Vaze, J. & $\begin{array}{l}\text { Csiro land and } \\
\text { water flagship }\end{array}$ & Australia & 2 & 0.53 \\
\hline Maier, H. R. & $\begin{array}{l}\text { University of } \\
\text { adelaide }\end{array}$ & Australia & 2 & 0.44 \\
\hline Madsen, $\mathrm{H}_{\text {., }}$ & DHI, Horsholm & Denmark & 2 & 0.38 \\
\hline Chiew, F. H. & $\begin{array}{l}\text { Cairo water for a } \\
\text { healthy country } \\
\text { national research } \\
\text { flagship }\end{array}$ & Australia & 2 & 0.36 \\
\hline XU, C.-Y. & University of Oslo & Norway & 2 & 0.35 \\
\hline Wang, D., & $\begin{array}{l}\text { national research } \\
\text { council regina }\end{array}$ & Canada & 2 & 0.34 \\
\hline Mahé, G., & $\begin{array}{l}\text { Hydrsciences } \\
\text { montpellier }\end{array}$ & France & 2 & 0.33 \\
\hline $\begin{array}{l}\text { Willem } \\
\text { Bouten }\end{array}$ & $\begin{array}{l}\text { University of } \\
\text { Amsterdam }\end{array}$ & $\begin{array}{l}\text { Netherlan } \\
\text { ds }\end{array}$ & 2 & 0.29 \\
\hline Zappa, M. & $\begin{array}{l}\text { Swiss federal } \\
\text { research institute }\end{array}$ & $\begin{array}{l}\text { Switzerlan } \\
\text { d }\end{array}$ & 2 & 0.27 \\
\hline Larry band & $\begin{array}{l}\text { City University of } \\
\text { New York }\end{array}$ & USA & 2 & 0.24 \\
\hline Li, M. & $\begin{array}{l}\text { Cairo land and } \\
\text { water flagship }\end{array}$ & Australia & 2 & 0.20 \\
\hline Dezetter, A. & $\begin{array}{l}\text { hydrsciences } \\
\text { montpellier }\end{array}$ & France & 2 & 0.19 \\
\hline $\begin{array}{l}\text { Refsgaard, } \\
\text { J. C. }\end{array}$ & $\begin{array}{ll}\text { University } & \text { of } \\
\text { copenhagen } & \end{array}$ & Denmark & 2 & 0.19 \\
\hline Servat, E. & $\begin{array}{l}\text { Hydrsciences } \\
\text { montpellier }\end{array}$ & France & 2 & 0.18 \\
\hline
\end{tabular}

\begin{tabular}{lllcc}
\hline Researchers & \multicolumn{1}{c}{ Affiliation } & Country & $\begin{array}{c}\text { No. of } \\
\text { papers }\end{array}$ & Score \\
\hline Lee, H.-J. & $\begin{array}{l}\text { National institute } \\
\text { of environmental } \\
\text { research }\end{array}$ & Korean & 2 & 0.17 \\
\hline
\end{tabular}

Table 5 illustrated the research center with the location of the center in country, number of researchers, number of papers and number of scores. In overall, the highest contribution of researchers is from the Lancaster University, United Kingdom which has a score point of 9.93 by producing 15 papers from 5 researchers. The University of Arizona, USA and the research center in post hydrology modelling, University of Lovisiana, US were the second and third ranked centers/university, as shown in Table 5. These centers/university have scored of 6.64 and 4.40 point, respectively.

As a result, it is important to analyze the citation of target papers to further appraise contributions of a specific author on publications. The citation for each journal had been obtained from Google Scholar. This search engine was used due to its wide coverage of citation report for all fields and analysis using this engine is consistent and reliable in nature [24] and continuously updated. They also added that Scopus search engine, which had been used for the analyses shown in Tables 2, 3 and 4, have limitations in terms of its coverage in the citation report of the most contributive papers. Most frequently cited paper was listed in Table 6. The top ten (10) most cited papers were published by Elsevier (4), Wiley (4), Taylor \& Francis (1) and ASCE (1). The paper entitled "The future of distributed models: model calibration and uncertainty prediction" written by Beven and Binley in 1992 has been cited for 3,731 times which ranked it to the first place [28].

Table 5 Research centre with the highest scores

\begin{tabular}{|c|c|c|c|c|}
\hline $\begin{array}{l}\text { Research } \\
\text { centre }\end{array}$ & Country & $\begin{array}{l}\text { Number of } \\
\text { researches }\end{array}$ & $\begin{array}{c}\text { Number } \\
\text { of } \\
\text { papers }\end{array}$ & Score \\
\hline $\begin{array}{l}\text { Lancaster } \\
\text { University }\end{array}$ & UK & 5 & 12 & 9.93 \\
\hline $\begin{array}{l}\text { University of } \\
\text { Arizona }\end{array}$ & USA & 12 & 9 & 6.64 \\
\hline $\begin{array}{l}\text { Lovisiana } \\
\text { State } \\
\text { University }\end{array}$ & USA & 7 & 7 & 4.40 \\
\hline $\begin{array}{l}\text { University of } \\
\text { Western } \\
\text { Australia, }\end{array}$ & Australia & 4 & 7 & 4.17 \\
\hline $\begin{array}{l}\text { National } \\
\text { hydrology } \\
\text { research } \\
\text { institute }\end{array}$ & Canada & 3 & 2 & 2.00 \\
\hline $\begin{array}{l}\text { University of } \\
\text { Adelaide }\end{array}$ & Australia & 7 & 2 & 2.00 \\
\hline $\begin{array}{l}\text { Rhodes } \\
\text { University }\end{array}$ & $\begin{array}{l}\text { South } \\
\text { Africa }\end{array}$ & 3 & 2 & 2.00 \\
\hline $\begin{array}{l}\text { Princeton } \\
\text { University }\end{array}$ & USA & 4 & 6 & 1.83 \\
\hline UNESCO- & Netherlan & 6 & 3 & 1.82 \\
\hline
\end{tabular}




\begin{tabular}{|c|c|c|c|c|}
\hline $\begin{array}{l}\text { Research } \\
\text { centre }\end{array}$ & Country & $\begin{array}{l}\text { Number of } \\
\text { researches }\end{array}$ & $\begin{array}{l}\text { Number } \\
\text { of } \\
\text { papers }\end{array}$ & Score \\
\hline $\begin{array}{l}\text { IHE Institute } \\
\text { for water } \\
\text { education }\end{array}$ & ds & & & \\
\hline $\begin{array}{l}\text { Nonwegian } \\
\text { water } \\
\text { resources } \\
\text { and energy } \\
\text { directorate }\end{array}$ & Norway & 4 & 3 & 1.64 \\
\hline $\begin{array}{l}\text { University of } \\
\text { bologna }\end{array}$ & Italy & 6 & 2 & 1.60 \\
\hline $\begin{array}{l}\text { University of } \\
\text { Tehran }\end{array}$ & Iran & 4 & 2 & 1.60 \\
\hline $\begin{array}{l}\text { Nanjing } \\
\text { university }\end{array}$ & China & 8 & 2 & 1.58 \\
\hline $\begin{array}{l}\text { University of } \\
\text { regina }\end{array}$ & Canada & 8 & 2 & 1.55 \\
\hline $\begin{array}{l}\text { Texas A \& } \\
\text { M } \\
\text { University, }\end{array}$ & USA & 2 & 4 & 1.48 \\
\hline $\begin{array}{l}\text { DHI, } \\
\text { Horsholm }\end{array}$ & Denmark & 6 & 2 & 1.43 \\
\hline $\begin{array}{l}\text { University of } \\
\text { California }\end{array}$ & USA & 4 & 3 & 1.29 \\
\hline $\begin{array}{l}\text { Uppsala } \\
\text { University }\end{array}$ & Sweden & 1 & 2 & 1.20 \\
\hline $\begin{array}{l}\text { University of } \\
\text { Stuttgart }\end{array}$ & Germany & 3 & 2 & 1.19 \\
\hline $\begin{array}{l}\text { Delft } \\
\text { university of } \\
\text { technology }\end{array}$ & $\begin{array}{l}\text { Netherlan } \\
\text { ds }\end{array}$ & 3 & 2 & 1.19 \\
\hline $\begin{array}{l}\text { University of } \\
\text { florida }\end{array}$ & USA & 3 & 2 & 1.18 \\
\hline $\begin{array}{l}\text { Geological } \\
\text { survey of } \\
\text { denmark }\end{array}$ & Denmark & 4 & 2 & 1.10 \\
\hline $\begin{array}{l}\text { University of } \\
\text { Amsterdam }\end{array}$ & $\begin{array}{l}\text { Netherlan } \\
\text { ds }\end{array}$ & 2 & 4 & 1.10 \\
\hline $\begin{array}{l}\text { The } \\
\text { Australian } \\
\text { National } \\
\text { University }\end{array}$ & Australia & 1 & 2 & 1.07 \\
\hline $\begin{array}{l}\text { Colorado } \\
\text { State Univ }\end{array}$ & USA & 4 & 4 & 1.07 \\
\hline $\begin{array}{l}\text { University of } \\
\text { oslo }\end{array}$ & Norway & 4 & 2 & 1.03 \\
\hline $\begin{array}{l}\text { University of } \\
\text { California }\end{array}$ & USA & 2 & 2 & 0.91 \\
\hline $\begin{array}{l}\text { Imperial } \\
\text { College of } \\
\text { Science, } \\
\text { Technology } \\
\text { and } \\
\text { Medicine }\end{array}$ & UK & 3 & 3 & 0.64 \\
\hline $\begin{array}{l}\text { Chinese } \\
\text { Academy } \\
\text { of Sciences }\end{array}$ & China & 2 & 2 & 0.60 \\
\hline $\begin{array}{l}\text { Sun Yat-sen } \\
\text { University }\end{array}$ & China & 2 & 2 & 0.47 \\
\hline $\begin{array}{l}\text { University of } \\
\text { Oslo }\end{array}$ & Norway & 1 & 2 & 0.44 \\
\hline $\begin{array}{l}\text { CRC for } \\
\text { Catchment } \\
\text { Hydrology, } \\
\text { CSIRO Land }\end{array}$ & Australia & 2 & 2 & 0.30 \\
\hline
\end{tabular}

\begin{tabular}{lcccc}
\hline $\begin{array}{l}\text { Research } \\
\text { centre }\end{array}$ & Country & $\begin{array}{c}\text { Number of } \\
\text { researches }\end{array}$ & $\begin{array}{c}\text { Number } \\
\text { of } \\
\text { papers }\end{array}$ & Score \\
\hline $\begin{array}{l}\text { and Water, } \\
\text { Canberra, } \\
\text { Australia }\end{array}$ & & & \\
\hline $\begin{array}{l}\text { City } \\
\text { University of USA }\end{array}$ & 1 & 2 & 0.24 \\
New York & & & & \\
\hline
\end{tabular}

It is interesting to note that, the research origin, active researchers, research centre and the most cited papers are from the United States and United Kingdom. Keith Beven was found to be the most active researcher in hydrological modelling field until to date. In general, countries such as United States and United Kingdom have met the expectation as developed countries with top ranked research universities which had spurred the growth in hydrological modelling studies. In addition each country itself had experienced many environmental and hydrological related disasters including flood and hurricanes which require real effective application in hydrological modelling.

\subsection{CONCLUSION}

Research in hydrological modelling has a wide range of applications in environmental management especially in water resources planning, management, and development. However, there are some limitations and challenges due to resource constraints and limited range of available measurement techniques. This study conducted a three round literature review of published journal papers to investigate the most popular and cited work in hydrology modelling field. Using the web of sciences search engine, the author adopted a combination of keyword, title, abstract and main text to identify 139 target papers to study past trends. As one of the most developed countries in the world, the United States leads in the research origin of publications in hydrology modelling. Keith Beven from Lancaster University, United Kingdom is ranked as the most active researcher in hydrological modelling publications. The Lancaster University has recorded the highest score in research center. Paper by Keith Beven and Andrew Binley was the most cited with 3731 citations. In conclusion, the post hydrological modelling research trends have provided a holistic review for other researchers to find a platform in a new field. The wide range opportunities available in post research hydrological modelling in terms of patterns, themes and active researchers allow the becoming researcher to discover new issues and develop new techniques and approach in hydrological modelling field. The information in this paper can also be used to identify the new network between the countries that have a similar research interest. 
Table 6 Most cited papers

\begin{tabular}{|c|c|c|}
\hline Author/published year & Paper title & $\begin{array}{l}\text { No. of times } \\
\text { cited }\end{array}$ \\
\hline Beven, K., \& Binley, A. (1992). [28] & $\begin{array}{l}\text { The future of distributed models: model calibration and } \\
\text { uncertainty prediction (Wiley). }\end{array}$ & 3731 \\
\hline Beven, K. (1989). [29] & $\begin{array}{l}\text { Changing ideas in hydrology-the case of physically- } \\
\text { based models (Elsevier). }\end{array}$ & 1792 \\
\hline Beven, K., \& Freer, J. (2001). [30] & $\begin{array}{l}\text { Equifinality, data assimilation, and uncertainty estimation } \\
\text { in mechanistic modelling of complex environmental } \\
\text { systems using the GLUE methodology (Elsevier). }\end{array}$ & 1641 \\
\hline Blöschl, G., \& Sivapalan, M. (1995). [20] & Scale issues in hydrological modelling: a review (Wiley) & 1619 \\
\hline $\begin{array}{l}\text { Hsu, K. I., Gupta, H. V., \& Sorooshian, S. } \\
\text { (1995). [31] }\end{array}$ & $\begin{array}{l}\text { Artificial neural network modeling of the rainfall-runoff } \\
\text { process (Wiley). }\end{array}$ & 1378 \\
\hline Beven, K. (1993). [32] & $\begin{array}{l}\text { Prophecy, reality and uncertainty in distributed } \\
\text { hydrological modelling (Elsevier). }\end{array}$ & 1170 \\
\hline $\begin{array}{l}\text { Vrugt, J. A., Gupta, H. V., Bouten, W., \& } \\
\text { Sorooshian, S. (2003). [33] }\end{array}$ & $\begin{array}{l}\text { A Shuffled Complex Evolution Metropolis algorithm for } \\
\text { optimization and uncertainty assessment of hydrologic } \\
\text { model parameters (Wiley). }\end{array}$ & 1013 \\
\hline Klemeš, V. (1986). [16] & $\begin{array}{l}\text { Operational testing of hydrological simulation models } \\
\text { (Taylor \& Francis). }\end{array}$ & 793 \\
\hline Singh, V. P., \& Woolhiser, D. A. (2002). [34] & Mathematical modeling of watershed hydrology (ASCE). & 784 \\
\hline $\begin{array}{l}\text { Wood, E. F., Sivapalan, M., Beven, K., \& } \\
\text { Band, L. (1988). [27] }\end{array}$ & $\begin{array}{l}\text { Effects of spatial variability and scale with implications } \\
\text { to hydrologic modeling (Elsevier). }\end{array}$ & 758 \\
\hline Beven, K. (2001). [35] & How far can we go in distributed hydrological modelling? & 682 \\
\hline $\begin{array}{l}\text { Moradkhani, H., Sorooshian, S., Gupta, H. } \\
\text { V., \& Houser, P. R. (2005). [36] }\end{array}$ & $\begin{array}{l}\text { Dual state-parameter estimation of hydrological models } \\
\text { using ensemble Kalman filter. }\end{array}$ & 647 \\
\hline $\begin{array}{l}\text { Vrugt, J. A., Gupta, H. V., Bastidas, L. A., } \\
\text { Bouten, W., \& Sorooshian, S. (2003). [37] }\end{array}$ & $\begin{array}{l}\text { Effective and efficient algorithm for multiobjective } \\
\text { optimization of hydrologic models. }\end{array}$ & 561 \\
\hline Beven, K. J. (1990). [38] & A discussion of distributed hydrological modelling. & 546 \\
\hline $\begin{array}{l}\text { Moradkhani, H., Hsu, K. L., Gupta, H., \& } \\
\text { Sorooshian, S. (2005).[39] }\end{array}$ & $\begin{array}{l}\text { Uncertainty assessment of hydrologic model states and } \\
\text { parameters: Sequential data assimilation using the } \\
\text { particle filter. }\end{array}$ & 464 \\
\hline $\begin{array}{l}\text { Wagener, T., Sivapalan, M., Troch, P., \& } \\
\text { Woods, R. (2007). [40] }\end{array}$ & Catchment classification and hydrologic similarity. & 448 \\
\hline Beven, K. J. (2000). [41] & $\begin{array}{l}\text { Uniqueness of place and process representations } \\
\text { in hydrological modelling. }\end{array}$ & 424 \\
\hline Beven, K. (2002). [42] & $\begin{array}{l}\text { Towards an alternative blueprint for a physically based } \\
\text { digitally simulated hydrologic response modelling system. }\end{array}$ & 424 \\
\hline $\begin{array}{l}\text { Wagener, T., Boyle, D. P., Lees, M. J., } \\
\text { Wheater, H. S., Gupta, H. V., \& Sorooshian, } \\
\text { S. (2001). [43] }\end{array}$ & $\begin{array}{l}\text { A framework for development and application of } \\
\text { hydrological models. }\end{array}$ & 421 \\
\hline $\begin{array}{l}\text { Ajami, N. K., Duan, Q., \& Sorooshian, S. } \\
\text { (2007). [44] }\end{array}$ & $\begin{array}{l}\text { An integrated hydrologic Bayesian multimodel } \\
\text { combination framework: Confronting input, parameter, } \\
\text { and model structural uncertainty in hydrologic prediction. }\end{array}$ & 393 \\
\hline Mishra, A. K., \& Singh, V.P. (2011). [45] & Drought modeling-A review. & 369 \\
\hline $\begin{array}{l}\text { Butts, M. B., Payne, J. T., Kristensen, M., \& } \\
\text { Madsen, H. (2004). [46] }\end{array}$ & $\begin{array}{l}\text { An evaluation of the impact of model structure on } \\
\text { hydrological modelling uncertainty for streamflow } \\
\text { simulation. }\end{array}$ & 328 \\
\hline Beven, K. (1995). [47] & $\begin{array}{l}\text { Linking parameters across scales: subgrid } \\
\text { parameterizations and scale dependent hydrological } \\
\text { models. }\end{array}$ & 328 \\
\hline $\begin{array}{l}\text { Sivapalan, M., Blöschl, G., Zhang, L., \& } \\
\text { Vertessy, R. (2003). [48] }\end{array}$ & Downward approach to hydrological prediction. & 326 \\
\hline $\begin{array}{l}\text { Jiang, T., Chen, Y. D., Xu, C.-y., Chen, X., } \\
\text { Chen, X., \& Singh, V.P. (2007). [49] }\end{array}$ & $\begin{array}{l}\text { Comparison of hydrological impacts of climate change } \\
\text { simulated by six hydrological models in the Dongjiang } \\
\text { Basin, South China. }\end{array}$ & 303 \\
\hline Sorooshian, S., \& Gupta, V. K. (1983). [50] & $\begin{array}{l}\text { Automatic calibration of conceptual rainfall-runoff } \\
\text { models: The question of parameter observability and } \\
\text { uniqueness. }\end{array}$ & 290 \\
\hline Singh, V. (1997). [51] & The use of entropy in hydrology and water resources. & 282 \\
\hline $\begin{array}{l}\text { Ajami, N. K., Gupta, H., Wagener, T., \& } \\
\text { Sorooshian, S. (2004). [52] }\end{array}$ & $\begin{array}{l}\text { Calibration of a semi-distributed hydrologic model for } \\
\text { streamflow estimation along a river system. }\end{array}$ & 251 \\
\hline Sivapalan, M. (2005). [53] & $\begin{array}{l}\text { Pattern, process and function: elements of a unified } \\
\text { theory of hydrology at the catchment scale. }\end{array}$ & 250 \\
\hline Xu, C.-Y., \& Singh, V.P. (2004). [54] & $\begin{array}{l}\text { Review on regional water resources assessment models } \\
\text { under stationary and changing climate. }\end{array}$ & 239 \\
\hline Singh, V. (1997). [55] & Effect of spatial and temporal variability in rainfall and & 234 \\
\hline
\end{tabular}




\begin{tabular}{|c|c|c|}
\hline Author/published year & Paper title & $\begin{array}{l}\text { No. of times } \\
\text { cited }\end{array}$ \\
\hline & watershed characteristics on stream flow hydrograph. & \\
\hline Xu, C.-Y., \& Singh, V. P. (1998). [56] & $\begin{array}{l}\text { A review on monthly water balance models for water } \\
\text { resources investigations. }\end{array}$ & 234 \\
\hline $\begin{array}{l}\text { Strupczewski, W., Singh, V., \& Feluch, W. } \\
\text { (2001). [57] }\end{array}$ & $\begin{array}{l}\text { Non-stationary approach to at-site flood frequency } \\
\text { modelling I. Maximum likelihood estimation. }\end{array}$ & 211 \\
\hline $\begin{array}{l}\text { Hsu, K. I., Gupta, H. V., Gao, X., } \\
\text { Sorooshian, S., \& Imam, B. (2002). [58] }\end{array}$ & $\begin{array}{l}\text { Self-organizing linear output map (SOLO): An artificial } \\
\text { neural network suitable for hydrologic modeling and } \\
\text { analysis. }\end{array}$ & 199 \\
\hline $\begin{array}{l}\text { Beven, K. J., Wood, E. F., \& Sivapalan, M. } \\
\text { (1988). [59] }\end{array}$ & $\begin{array}{l}\text { On hydrological heterogeneity-catchment morphology } \\
\text { and catchment response. }\end{array}$ & 191 \\
\hline $\begin{array}{l}\text { Jin, X., XU, C.-Y., Zhang, Q., \& Singh, V. } \\
\text { (2010). [60] }\end{array}$ & $\begin{array}{l}\text { Parameter and modeling uncertainty simulated by GLUE } \\
\text { and a formal Bayesian method for a conceptual } \\
\text { hydrological model. }\end{array}$ & 190 \\
\hline $\begin{array}{l}\text { Efstratiadis, A., \& Koutsoyiannis, D. (2010). } \\
\text { [61] }\end{array}$ & $\begin{array}{l}\text { One decade of multi-objective calibration approaches in } \\
\text { hydrological modelling: a review. }\end{array}$ & 183 \\
\hline Singh, V. P., \& Frevert, D. K. (2003). [62] & Watershed modeling. & 178 \\
\hline Mishra, S. K., \& Singh, V. P. (2004). [63] & $\begin{array}{l}\text { Long-term hydrological simulation based on the Soil } \\
\text { Conservation Service curve number. }\end{array}$ & 148 \\
\hline Gupta, V. K., \& Sorooshian, S. (1985). [64] & $\begin{array}{l}\text { The relationship between data and the precision of } \\
\text { parameter estimates of hydrologic models. }\end{array}$ & 147 \\
\hline Kite, G., \& Pietroniro, A. (1996). [65] & Remote sensing applications in hydrological modelling. & 126 \\
\hline $\begin{array}{l}\text { Bastola, S., Murphy, C., \& Sweeney, J. } \\
\text { (2011). [66] }\end{array}$ & $\begin{array}{l}\text { The role of hydrological modelling uncertainties in climate } \\
\text { change impact assessments of Irish river catchments. }\end{array}$ & 123 \\
\hline $\begin{array}{l}\text { Blöschl, G., Grayson, R. B., \& Sivapalan, M. } \\
\text { (1995). [67] }\end{array}$ & $\begin{array}{l}\text { On the representative elementary area (REA) concept } \\
\text { and its utility for distributed rainfall-runoff modelling. }\end{array}$ & 108 \\
\hline $\begin{array}{l}\text { Albek, M., Öğütveren, Ü. B., \& Albek, E. } \\
\text { (2004). [68] }\end{array}$ & $\begin{array}{l}\text { Hydrological modeling of Seydi Suyu watershed (Turkey) } \\
\text { with HSPF. }\end{array}$ & 105 \\
\hline Kim, J.-Y., \& Sansalone, J. J. (2008). [69] & $\begin{array}{l}\text { Event-based size distributions of particulate matter } \\
\text { transported during urban rainfall-runoff events. }\end{array}$ & 103 \\
\hline Sivapalan, M., \& Kalma, J. D. (1995). [70] & $\begin{array}{l}\text { Scale problems in hydrology: Contributions of the } \\
\text { Robertson Workshop. }\end{array}$ & 97 \\
\hline $\begin{array}{l}\text { Du, J., Qian, L., Rui, H., Zuo, T., Zheng, D., } \\
\text { Xu, Y., \& Xu, C.-Y. (2012). [71] }\end{array}$ & $\begin{array}{l}\text { Assessing the effects of urbanization on annual runoff and } \\
\text { flood events using an integrated hydrological modeling } \\
\text { system for Qinhuai River basin, China. }\end{array}$ & 96 \\
\hline Cole, S. J., \& Moore, R. J. (2008). [72] & $\begin{array}{l}\text { Hydrological modelling using raingauge-and radar- } \\
\text { based estimators of areal rainfall. }\end{array}$ & 93 \\
\hline $\begin{array}{l}\text { Poulin, A., Brissette, F., Leconte, R., } \\
\text { Arsenault, R., \& Malo, J.-S. (2011). [73] }\end{array}$ & $\begin{array}{l}\text { Uncertainty of hydrological modelling in climate change } \\
\text { impact studies in a Canadian, snow-dominated river } \\
\text { basin. }\end{array}$ & 82 \\
\hline Xie, X., \& Cui, Y. (2011). [74] & $\begin{array}{l}\text { Development and test of SWAT for modeling hydrological } \\
\text { processes in irrigation districts with paddy rice. }\end{array}$ & 79 \\
\hline $\begin{array}{l}\text { Stehr, A., Debels, P., Romero, } \text { F., }^{\text {\& }} \\
\text { Alcayaga, H. (2008). [75] }\end{array}$ & $\begin{array}{l}\text { Hydrological modelling with SWAT under conditions of } \\
\text { limited data availability: evaluation of results from a } \\
\text { Chilean case study. }\end{array}$ & 75 \\
\hline Sutcliffe, J., \& Parks, Y. (1987). [76] & Hydrological modelling of the Sudd and Jonglei Canal. & 69 \\
\hline $\begin{array}{l}\text { Menabde, M., Veitzer, S., Gupta, V., \& } \\
\text { Sivapalan, M. (2001). [77] }\end{array}$ & $\begin{array}{l}\text { Tests of peak flow scaling in simulated self-similar river } \\
\text { networks. }\end{array}$ & 63 \\
\hline $\begin{array}{l}\text { Keskin, M. E., Taylan, D., \& Terzi, O. (2006). } \\
\text { [78] }\end{array}$ & $\begin{array}{l}\text { Adaptive neural-based fuzzy inference system (ANFIS) } \\
\text { approach for modelling hydrological time series. }\end{array}$ & 62 \\
\hline Abebe, A., \& Price, R. (2003). [79] & $\begin{array}{l}\text { Managing uncertainty in hydrological models using } \\
\text { complementary models. }\end{array}$ & 56 \\
\hline $\begin{array}{l}\text { Sivapalan, M., Viney, N. R., \& Jeevaraj, C. } \\
\text { G. (1996). [80] }\end{array}$ & $\begin{array}{l}\text { Water and salt balance modelling to predict the effects } \\
\text { of land-use changes in forested catchments. } 3 \text {. The large } \\
\text { catchment model. }\end{array}$ & 53 \\
\hline $\begin{array}{l}\text { Kannan, N., White, S., Worrall, F., \& } \\
\text { Whelan, M. (2007). [81] }\end{array}$ & $\begin{array}{l}\text { Hydrological modelling of a small catchment using SWAT- } \\
2000-\text { Ensuring correct flow partitioning for contaminant } \\
\text { modelling. }\end{array}$ & 50 \\
\hline $\begin{array}{l}\text { Kingston, G. B., Maier, H. R., \& Lambert, M. } \\
\text { F. (2005). [82] }\end{array}$ & $\begin{array}{l}\text { Calibration and validation of neural networks to ensure } \\
\text { physically plausible hydrological modeling. }\end{array}$ & 50 \\
\hline
\end{tabular}




\section{Acknowledgement}

The authors would like to thank Institute of Research Management and Innovation, Universiti Teknologi MARA, Malaysia (IRMI, UiTM) for funding this project under Research Entity Initiative (REI) (600-IRMI/DANA 5/3/REI (0006/2016)). Additional funding provided by Universiti Kebangsaan Malaysia to Nur Shazwani Muhammad, Siti Asiah Muhammad and Noor Farahain Mohammad through Geran Galakan Penyelidik Muda (GGPM-2014-046) is also gratefully acknowledged.

\section{References}

[1] Mikkelsen, P. S., Madsen, H., Arnbjerg-Nielsen, K., Rosbjerg, D., and Harremoes, P. 2005. Selection of Regional Historical Rainfall Time Series as Input to Urban Drainage Simulations at Ungauged Locations. Atmospheric Research. 77: 4-17.

[2] FutureWater (Producer). Hydrological Modeling. Retrieved from http://www.futurewater.eu/methods/modeling/.

[3] Devia, G. K., Ganasri, B. and Dwarakish G. 2015. A Review on Hydrological Models. Aquatic Procedia. 4: 1001-1007.

[4] Chandwani, V., Vyas, S. K, Agrawal, V. and Sharma, G. 2015. Soft Computing Approach for Rainfall-runoff Modelling: A Review. Aquatic Procedia. 4: 1054-1061.

[5] Elsafi, S. H. 2014. Artificial Neural Networks (ANNs) for Flood Forecasting at Dongola Station in the River Nile, Sudan. Alexandria Engineering Journal. 53(3): 655-662.

[6] Wang, Y., Wang, H., Lei, X., Jiang, Y. and Song, X. 2011. Flood Simulation Using Parallel Genetic Algorithm Integrated Wavelet Neural Networks. Neurocomputing. 74(17): 2734-2744.

[7] Perera, E. D. P. and Lahat, L. 2015. Fuzzy logic Based Flood Forecasting Model for the Kelantan River Basin, Malaysia. Journal of Hydro-environment Research. 9(4): 542-553.

[8] Primozic, M., Kobold, M. and Brilly, M. 2008. The Implementation of the HBV Model on the Sava River Basin. IOP Conference Series: Earth and environmental Science. IOP Publishing. 4(1).

[9] Gao, J., Holden, J. and Kirkby, M. 2017. Modelling Impacts of Agricultural Practice on Flood Peaks in Upland Catchments: An Application of the Distributed TOPMODEL. Hydrological Processes. 31 (23): 4206-4216.

[10] Thompson, J. R., Iravani, H., Clilverd, H. M., Sayer, C. D. Heppell, C. M. and Axmacher, J. C. 2017. Simulation of the Hydrological Impacts of Climate Change on a Restored Floodplain. Hydrological Sciences Journal. 62(15): 24822510.

[11] Swain, S., Verma, M. K. and Verma, M. 2018. Streamflow Estimation Using SWAT Model Over Seonath River Basin, Chhattisgarh, India. Hydrologic Modeling. 81: 659-665.

[12] Abdullah, J., Muhammad, N., Julien, P., Ariffin, J. and Shafie, A. 2018. Flood Flow Simulations and Return Period Calculation for the Kota Tinggi Watershed, Malaysia. Journal of Flood Risk Management. 11 (2): S766-S782.

[13] Blomqvist, E. M., Bonsdorff, E. and Essink, K. 2013. Biological, Physical and Geochemical Features of Enclosed and Semi-enclosed Marine Systems. Proceedings of the Joint BMB 15 and ECSA 27 Symposium, 9-13 June 1997, Åland Islands, Finland.

[14] Wheater, H., Sorooshian, S. and Sharma, K. D. 2007. Hydrological Modelling in Arid and Semi-arid Areas. Cambridge University Press.

[15] Weber, T., Stewart, J., Anderssen, R., Braddock, R. and Newham, L. 2009. Benefits and Limitations of Current Approaches to Whole of Catchment Modelling. Proceedings of the 18th World IMACS Congress and
MODSIM09 International Congress on Modelling and Simulation, Cairns, Australia.

[16] Klemes, V. 1986. Operational Testing of Hydrological Simulation Models. Hydrological Sciences Journal. 31(1): 13-24

[17] Biswal, B. and Singh, R. 2017. Incorporating Channel Network Information in Hydrologic Response Modelling: Development of a Model and Inter-model Comparison. Advances in Water Resources. 100: 168-182.

[18] Ranatunga, T., Tong, S. T. and Yang, Y. J. 2017. Approach to Measure Parameter Sensitivity in Watershed Hydrological Modelling. Hydrological Sciences Journal. 62(1): 76-92

[19] Hanington, P., Toan, T. Q., Vu, D. N. A. and Kiem, A. S 2017. A Hydrological Model for Interprovincial Water Resource Planning and Management: A Case Study in the Long Xuyen Quadrangle, Mekong Delta, Vietnam. Journal of Hydrology. 547: 1-9.

[20] Bloschl, G. and Sivapalan, M. 1995. Scale Issues in Hydrological Modelling: A Review. Hydrological Processes. 9(3-4): 251-290.

[21] XU, C-y., Widen, E. and Halldin, S. 2005. Modelling Hydrological Consequences of Climate Change Progress and Challenges. Advances in Atmospheric Sciences. 22(6): 789-797

[22] Tsai, C. C. and Lydia, Wen. M. 2005. Research and Trends in Science Education from 1998 to 2002: A Content Analysis of Publication in Selected Journals. International Journal of Science Education. 27(1): 3-14.

[23] Ke, Y., Wang, S., Chan, A.P., and Cheung, E. 2009. Research Trend of Public-private Partnership in Construction Journals. Journal of Construction Engineering and Management. 135(10): 1076-1086.

[24] Hong, Y. and W. M. Chan, D. 2014 Research Trend of Joint Ventures in Construction: A Two-decade Taxonomic Review. Journal of Facilities Management. 12(2): 118-141.

[25] Yi, H. and Wang, Y. 2013. Trend of the Research on Public Funded Projects. Open Construction and Building Technology Journal. 7: 51-62.

[26] Howard, G. S., Cole, D. A. and Maxwell, S. E. 1987. Research Productivity in Psychology Based on Publication in the Journals of the American Psychological Association. American Psychologist. 42(11): 975-986.

[27] Wood, E. F., Sivapalan, M., Beven, K. and Band, L. 1988. Effects of Spatial Variability and Scale with Implications to Hydrologic Modeling. Journal of Hydrology. 102(1-4): 2947.

[28] Beven, K. and Binley, A. 1992. The Future of Distributed Models: Model Calibration and Uncertainty Prediction. Hydrological Processes. 6(3): 279-298.

[29] Beven, K. 1989. Changing Ideas in Hydrology-The Case of Physically-based Models. Journal of Hydrology. 105(1-2): 157-172.

[30] Beven, K. and Freer, J. Equifinality, Data Assimilation, and Uncertainty Estimation in Mechanistic Modelling of Complex Environmental Systems using the GLUE Methodology. Journal of Hydrology. 249(1-4): 11-29.

[31] Hsu, K. I., Gupta, H. V. and Sorooshian, S. 1995. Artificial Neural Network Modeling of the Rainfall-runoff Process. Water Resources Research. 31 (10): 2517-2530.

[32] Beven, K. 1993. Prophecy, Reality and Uncertainty in Distributed Hydrological Modelling. Advances in Water Resources. 16(1): 41-51.

[33] Vrugt, J. A., Gupta, H. V., Bouten, W. and Sorooshian, S. 2003. A Shuffled Complex Evolution Metropolis Algorithm for Optimization and Uncertainty Assessment of Hydrologic Model Parameters. Water Resources Research. 39 (8): 1201.

[34] Singh, V. P. and Woolhiser, D. A. 2002. Mathematical Modeling of Watershed Hydrology. Journal of Hydrologic Engineering. 7(4): 270-292.

[35] Beven, K. 2001. How Far Can We Go in Distributed Hydrological Modelling? Hydrology and Earth System Sciences. 5(1): 1-12. 
[36] Moradkhani, H., Sorooshian, S., Gupta, H. V. and Houser, P. R. 2005. Dual State-parameter Estimation of Hydrological Models Using Ensemble Kalman Filter. Advances in Water Resources. 28(2): 135-147.

[37] Vrugt, J. A., Gupta, H. V., Bastidas, L. A., Bouten, W. and Sorooshian, S. 2003. Effective and Efficient Algorithm for Multiobjective Optimization of Hydrologic Models. Water Resources Research. 39(8): 1214.

[38] Beven, K. J. 1990. A Discussion of Distributed Hydrological Modelling. Distributed Hydrological Modelling. 22: 255-278.

[39] Moradkhani, H., Hsu, K. L., Gupta, H. and Sorooshian, S. 2005. Uncertainty Assessment of Hydrologic Model States and Parameters: Sequential Data Assimilation Using the Particle Filter. Water Resources Research. 41 (5): 1-17

[40] Wagener, T., Sivapalan, M., Troch, P., and Woods, R. 2007. Catchment Classification and Hydrologic Similarity. Geography Compass. 1 (4): 901-931.

[41] Beven, K. J. 2000. Uniqueness of Place and Process Representations in Hydrological Modelling. Hydrology and Earth System Sciences. 4(2): 203-213.

[42] Beven, K. 2002. Towards an Alternative Blueprint for a Physically Based Digitally Simulated Hydrologic Response Modelling System. Hydrological Processes. 16(2): 189-206.

[43] Wagener, T., Boyle, D. P., Lees, M. J., Wheater, H. S., Gupta, H. V. and Sorooshian, S. 2001. A Framework for Development and Application of Hydrological Models. Hydrology and Earth System Sciences. 5(1): 13-26.

[44] Ajami, N. K., Duan, Q. and Sorooshian, S. 2007. An Integrated Hydrologic Bayesian Multimodel Combination Framework: Confronting Input, Parameter, and Model Structural Uncertainty in Hydrologic Prediction. Water Resources Research. 43(1): W01403.

[45] Mishra, A. K. and Singh, V. P. 2011. Drought Modeling-A Review. Journal of Hydrology. 403(1-2): 157-175.

[46] Butts, M. B., Payne, J. T., Kristensen, M. and Madsen, H. 2004. An Evaluation of the Impact of Model Structure on Hydrological Modelling Uncertainty for Streamflow Simulation. Journal of Hydrology. 298(1-4): 242-266.

[47] Beven, K. 1995. Linking Parameters Across Scales: Subgrid Parameterizations and Scale Dependent Hydrological Models. Hydrological Processes. 9(5-6): 507-525.

[48] Sivapalan, M., Bloschl, G., Zhang, L. and Vertessy, R. 2003. Downward Approach to Hydrological Prediction. Hydrological Processes. 17(11): 2101-2111.

[49] Jiang, T., Chen, Y. D., Xu, C-Y., Chen, X., Chen, X. and Singh, V.P. 2007. Comparison of Hydrological Impacts of Climate Change Simulated by Six Hydrological Models in the Dongjiang Basin, South China. Journal of Hydrology. 336(3-4): 316-333.

[50] Sorooshian, S. and Gupta, V.K. 1983. Automatic Calibration of Conceptual Rainfall-runoff Models: The Question of Parameter Observability and Uniqueness. Water Resources Research. 19(1): 260-268.

[51] Singh, V. 1997. The Use of Entropy in Hydrology and Water Resources. Hydrological Processes. 11 (6): 587-626.

[52] Ajami, N. K., Gupta, H., Wagener, T. and Sorooshian, S. 2004. Calibration of a Semi-distributed Hydrologic Model for Streamflow Estimation along A River System. Journal of Hydrology. 298(1-4): 112-135.

[53] Sivapalan, M. 2005. Pattern, Process and Function: Elements of a Unified Theory of Hydrology at the Catchment Scale. Encyclopedia of Hydrological Sciences. 1: 193-220

[54] Xu, C-Y. and Singh, V. P. 2004. Review on Regional Water Resources Assessment Models Under Stationary and Changing Climate. Water Resources Management. 18(6): 591-612.

[55] Singh, V. 1997. Effect of Spatial and Temporal Variability in Rainfall and Watershed Characteristics on Stream Flow Hydrograph. Hydrological Processes. 11 (12): 1649-1669.

[56] XU, C-Y. and Singh, V. P. 1998. A Review on Monthly Water Balance Models for Water Resources Investigations. Water Resources Management. 12(1): 20-50.
[57] Strupczewski, W. G., Singh, V. P. and Feluch, W. 2001. Nonstationary Approach to At-Site Flood Frequency Modelling I. Maximum Likelihood Estimation. Journal of Hydrology. 248(1): 123-142.

[58] Hsu, K. I., Gupta, H. V., Gao, X., Sorooshian, S. and Imam, B. 2002. Self-organizing Linear Output Map (SOLO): An Artificial Neural Network Suitable for Hydrologic Modeling and Analysis. Water Resources Research. 38(12): 381-3817

[59] Beven, K. J., Wood, E. F. and Sivapalan, M. 1988. On Hydrological Heterogeneity-Catchment Morphology and Catchment Response. Journal of Hydrology. 100(1-3): 353-375.

[60] Jin, X., XU, C-Y., Zhang, Q. and Singh, V. 2010. Parameter and Modeling Uncertainty Simulated by GLUE and a formal Bayesian Method for a Conceptual Hydrological Model. Journal of Hydrology. 383(3-4): 147-155.

[61] Efstratiadis, A. and Koutsoyiannis, D. 2010. One Decade of Multi-objective Calibration Approaches in Hydrological Modelling: A Review. Hydrological Sciences JournalJournal Des Sciences Hydrologiques. 55(1): 58-78.

[62] Singh, V. P. and Frevert, D. K. 2003. Watershed Modeling. World Water \& Environmental Resources Congress.

[63] Mishra, S. K. and Singh, V. P. 2004. Long-term Hydrological Simulation based on the Soil Conservation Service Curve Number. Hydrological Processes. 18(7): 1291-1313.

[64] Gupta, V. K. and Sorooshian, S. 1985. The Relationship between Data and the Precision of Parameter Estimates of Hydrologic Models. Journal of Hydrology. 81 (1-2): 57-77.

[65] Kite, G. and Pietroniro, A. 1996. Remote Sensing Applications in Hydrological Modelling. Hydrological Sciences Journal. 41 (1): 563-591.

[66] Bastola, S., Murphy, C. and Sweeney, J. 2011. The Role of Hydrological Modelling Uncertainties in Climate Change Impact Assessments of Irish River Catchments. Advances in Water Resources. 34(5): 562-576.

[67] Bloschl, G., Grayson, R. B. and Sivapalan, M. 1995. On the Representative Elementary Area (REA) Concept and Its Utility for Distributed Rainfall-runoff Modelling. Hydrological Processes. 9(3-4): 313-330.

[68] Albek, M., Ogutveren, U. B. and Albek, E. 2004. Hydrological Modeling of Seydi Suyu Watershed (Turkey) with HSPF. Journal of Hydrology. 285(1-4): 260-271.

[69] Kim, J-Y, and Sansalone, J. J. 2008. Event-based Size Distributions of Particulate Matter Transported during Urban Rainfall-runoff Events. Water Research. 42(10-11): 2756-2768.

[70] Sivapalan, M. and Kalma, J. D. 1995. Scale Problems in Hydrology: Contributions of the Robertson Workshop. Hydrological Processes. 9(3-4): 243-250.

[71] Du, J., Qian, L., Rui, H., Zuo, T., Zheng, D., Xu, Y. and Xu, CY. 2012. Assessing the Effects of Urbanization on Annual Runoff and Flood Events Using an Integrated Hydrological Modeling System for Qinhuai River Basin, China. Journal of Hydrology. 464-465: 127-139.

[72] Cole, S. J. and Moore, R. J. 2008. Hydrological Modelling Using Raingauge-and Radar-based Estimators of Areal Rainfall. Journal of Hydrology. 358(3-4): 159-181.

[73] Poulin, A., Brissette, F., Leconte, R., Arsenault, R. and Malo, J-S. 2011. Uncertainty of Hydrological Modelling in Climate Change Impact Studies in a Canadian, Snow-dominated River Basin. Journal of Hydrology. 409 (3-4): 626-636.

[74] Xie, X. and CU,i Y. 2011 . Development and Test of SWAT for Modeling Hydrological Processes in Irrigation Districts with Paddy Rice. Journal of Hydrology. 396(1): 61-71.

[75] Stehr, A., Debels, P., Romero, F. and Alcayaga, H. 2008. Hydrological Modelling with SWAT under Conditions of Limited Data Availability: Evaluation of Results from a Chilean Case Study. Hydrological Sciences Journal. 58(3): 588-601.

[76] Sutcliffe, J. and Parks, Y. 1987. Hydrological modelling of the Sudd and Jonglei Canal. Hydrological Sciences Journal. 32(2): 143-159.

[77] Menabde, M., Veitzer, S., Gupta, V. and Sivapalan, M. 2001. Tests of Peak Flow Scaling in Simulated Self-similar 
River Networks. Advances in Water Resources. 24(9-10): 991-999.

[78] Keskin, M. E., Taylan, D. and Terzi, O. 2006. Adaptive Neural-based Fuzzy Inference System (ANFIS) Approach for Modelling Hydrological Time Series. Hydrological Sciences Journal. 51 (4): 588-598.

[79] Abebe, A. and Price, R. Managing Uncertainty In Hydrological Models Using Complementary Models. Hydrological Sciences Journal. 48(5): 679-692.

[80] Sivapalan, M., Viney, N. R. and Jeevaraj, C. G. 1996. Water and Salt Balance Modelling to Predict the Effects of
Land-use Changes in Forested Catchments. 3. The Large Catchment Model. Hydrological Processes. 10(3): 429-446.

[81] Kannan, N., White, S., Worrall, F. and Whelan, M. 2007. Hydrological Modelling of a Small Catchment using SWAT2000-Ensuring Correct Flow Partitioning for Contaminant Modelling. Journal of Hydrology. 334(1-2): 64-72.

[82] Kingston, G. B., Maier, H. R. and Lambert, M. F. 2005. Calibration and Validation of Neural Networks to Ensure Physically Plausible Hydrological Modeling. Journal of Hydrology. 314(1): 158-176. 